\title{
Pembelajaran Teori Probabilitas Menggunakan R
}

\author{
Joko Sungkono a,1, ${ }^{*}$, Kriswianti Nugrahaningsih a,2 \\ a Pendidikan Matematika, Universitas Widya Dharma, Klaten, Indonesia \\ 1 jokosungkono@unwidha.ac.id*; ${ }^{2}$ kriswianti.th@gmail.com \\ * Corresponding Author
}

Diterima 6 September 2020; Disetujui 10 September 2020; published 22 Februari 2021

\section{ABSTRACT}

In learning probability theory, if a series of statistical experiments is carried out several times, identifying the possible samples produced is not an easy thing. If this happens, then a significant probability problem will arise. The objective of this study is how to learn probability theory using $R$ software. Based on the simulation results it can be concluded that by combining the syntax in $R$ can be used to solve probability problems such as identifying sample points from experiments, events, event operations, probabilities and conditional probabilities. This will help students learning in understanding of the probability theory material. The use of $\mathrm{R}$ will be very pronounced for experiments with $\mathrm{a}$ large enough scale that results in a large sample probability.
KEYWORDS

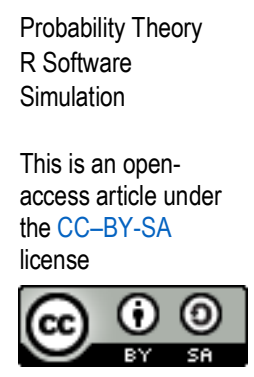

\section{Pendahuluan}

Teori probabilitas selalu dipahami mulai dari percobaan statistik yang menghasilkan ruang sampel. Percobaan yang sering digunakan untuk memahami teori probabilitas antara lain pelemparan mata uang, pelantunan dadu, pengambilan bola secara acak dari suatu kotak, dan pengambilan kartu bridge. Teori probabilitas secara sederhana sudah mulai diajarkan ketika bangku sekolah dasar. Menurut (Sari, Budayasa, and Juniati 2018), pembelajaran probabilistik di tingkat sekolah dasar merupakan fondasi yang kuat untuk mengembangkan berpikir probabilistik pada tahap berikutnya. Berpikir probabilistik dapat dilihat dari beberapa aspek, salah satunya adalah aspek respon (Sharma 2012). Respon ini merupakan cara bagaimana menjelaskan pemikirannya, apakah dengan menebak, menggunakan aturan yang ada, menghubungkan dengan kejadian nyata atau yang lain. Menurut (Sari 2015), jika berpikir probabilistik berkembang dengan baik, siswa SD akan mampu merespon serta menggunakan strategi dalam menyelesaikan permasalahan materi probabilitas. Teori Probabilitas adalah ukuran yang digunakan untuk mengetahui terjadinya atau tidak terjadinya suatu peristiwa. Sebuah peristiwa yang terjadi pasti mempunyai nilai peluang yang besarnya antara nilai nol dan nilai satu. Untuk peristiwa yang sudah pasti terjadi akan mempunyai peristiwa sebesar satu. Akan tetapi, peristiwa yang sudah pasti tidak akan terjadi mempunyai nilai peluang sebesar nol. Dalam hal ini kita jarang menjumpai sebuah peristiwa yang mempunyai nilai peluang tepat sama dengan nol dan atau tepat sama dengan satu. Kita sering menjumpai sebuah peristiwa yang mempunyai nilai peluang antara nol dan satu (Relawati and Defitriani 2018). Probabilitas diartikan sebagai suatu nilai yang dipergunakan untuk mengukur tingkat peluang terjadinya kejadian yang random. (Parsa 2013)

Menurut (Sirait and Purba 2018), salah satu peningkatan penguasaan kombinatorik pada pembelajaran probabilitas dapat dilakukan melalui penggunaan alat peraga, yaitu combination box. Siswa yang menguasai kombinatorik dengan baik akan mendukung pembelajaran probabilitas. Menurut (Aisyah, Sumintono, and Ismail 2014), urutan penyelesaian peristiwa kombinasi merupakan langkah penting dalam penyelesaian masalah yang melibatkan probabilitas. Menurut (Dalgaard 2008), tahap awal ketika mempelajari dan membahas teori probabilitas akan dimulai dari permainan dan gambling. Hal ini yang menjadi dasar tentang notasi sampel. Sebagai contoh pelemparan sebuah mata uang logam dengan sisi angka dan gambar yang dilakukan sekali, maka ruang sampel yang dihasilkan adalah $S=\{A, G\}$. Ruang sampel pada contoh percobaan ini dengan mudah dapat ditentukan. Jika rangkaian percobaan ini dilakukan beberapa kali maka identifikasi 
kemungkinan sampel yang dihasilkan sangat rumit. Sebagai contoh, jika pelemparan mata uang logam dilakukan sebanyak 6 kali, maka untuk identifikasi semua kemungkinan sampel bukan hal yang mudah.

Software $\mathrm{R}$ mempunyai mempunyai packages dasar bawaan yang berorientasi pada metode statistic, akan tetapi seiring perkembangannya banyak peneliti yang merancang packages-packages tambahan yang dapat meningkatkan kemampuan software R (Hartanto 2016). Packages tambahan yang akan digunakan dapat diinstall pada software $\mathrm{R}$ dan siap untuk digunakan.

Pada tulisan ini akan membahas tentang pembelajaran teori probabilitas melalui percobaanpercobaan statistik menggunakan Software R. Untuk mendalami percobaan pelemparan mata uang logam, pelantunan dadu, pengambilan bola secara acak dari kotak, dan pengambilan kartu bridge memerlukan packages prob dan packages combinat. Packages ini sudah memuat sintaks dasar percobaan statistic yang akan dibahas. Berdasarkan sintak dasar dapat dikembangkan untuk membentuk fungsi baru menggunakan perintah function() sesuai kebutuhan (William $\mathrm{N}$ Venables 2009). Pada penelitian ini fungsi yang dikembangkan merupakan kombinasi beberapa sintaks dasar untuk menyelesaikan permasalahan teori probabilitas.

\section{Metode}

Metode penelitian yang digunakan dalam tulisan ini adalah study literasi dan simulasi. Secara teori, probabilitas sudah banyak dibahas baik dalam bentuk buku maupun artikel. Study simulasi digunakan untuk memberi gambaran lebih detail tentang probabilitas serta menyelesaikan masalah probabilitas yang cukup rumit. Fase-fase dalam penelitian ini meliputi fase investigasi awal, fase desain, dan fase simulasi.

Pada fase investigasi awal. dipelajari percobaan-percobaan yang sering diangkat terkait topik probabilitas serta permasalahan yang sering muncul. Selain itu pada fase ini juga mempelajari packages-packages dan sintaks software $\mathrm{R}$ yang dibutuhkan.

Pada fase desain, dirancang algoritma atau langkah-langkah yang harus dilakukan untuk merancang percobaan serta permasalahan yang perlu diselesaikan. Sedangkan pada fase simulasi dilakukan simulasi berdasarkan kondisi yang telah dibangun, kemudian melakukan interpretasi hasil simulasi untuk menjawab permasalahan yang diselesaikan.

\section{Hasil dan Pembahasan}

Pada tulisan ini akan dibahas permasalahan teori probabilitas antara lain percobaan pelemparan mata uang logam, pelantunan dadu, pengambilan item dari kotak dan pengambilan kartu bridge. Simulasi dilakukan menggunakan software $\mathrm{R}$ dengan packages tambahan yang diperlukan adalah packages prob dan packages combinat. Materi probabilitas yang diangkat antara lain menentukan ruang sampel, operasi kejadian, peluang kejadian, peluang bersyarat dan independensi.

Pada percobaan pelemparan mata uang dalam $\mathrm{R}$ memerlukan packages "prob" sehingga diperlukan install packages "prob" dalam R. Selanjutnya sintaks dasar percobaan yang digunakan seperti ditunjukkan pada Gambar 1. Argumen "times" menunjukkan banyaknya pelemparan dan "makespace" menunjukkan ruang probabilitas yang terbentuk (Kerns 2011). Jika dilakukan perhitungan probabilitas maka argument "makespace" harus diisi dengan "T" atau "TRUE". Jika pada argument makespace diisi dengan "F" atau "FALSE", maka yang akan muncul hanya ruang sampel.

tosscoin (times, makespace=FALSE)

Gambar 1. Argumen Makespace

Sebagai contoh penggunaannya perhatikan kasus percobaan pelemparan mata uang logam dengan sisi "Head" $(\mathrm{H})$ dan "Tail" $(\mathrm{T})$ sebanyak 3 kali. Akan ditentukan ruang sampel percobaan tersebut, peluang munculnya tepat $2 \mathrm{H}$, dan peluang muncul minimal $1 \mathrm{H}$ dan $1 \mathrm{~T}$. Untuk menyelesaikan permasalahan pelemparan mata uang logam ini dibuat program di $\mathrm{R}$ dengan nama 
Misalkan B adalah kejadian munculnya minimal $1 \mathrm{H}$ dan 1T, makabanyaknya kejadian munculnya minimal $1 \mathrm{H}$ dan $1 \mathrm{~T}$ adalah $\mathrm{n}(\mathrm{B})=6$, yaitu HHT, HTH, THH, HTT, THT, TTH. Peluang kejadian munculnya minimal $1 \mathrm{H}$ dan $1 \mathrm{~T}$ adalah

$$
P(B)=\frac{n(B)}{n(S)}=\frac{6}{8}=0,75
$$

Hasil ini menunjukkan bahwa dengan menggunakan sintaks software $\mathrm{R}$ dapat dilakukan percobaan pelemparan mata uang serta menyelesaikan permasalahan teori probabilitasnya. Perhitungan manual dan pengerjaan dengan software $\mathrm{R}$ memberikan hasil yang sama.

Pada percobaan pelantunan dadu bersisi 6 secara umum menggunakan sintaks pada Gambar 5 dengan "times" menunjukkan banyaknya pelantunan, argument "nsides" menunjukkan banyakna sisi dadu yang dilantunkan dan "makespace" menunjukkan ruang probabilitas yang terbentuk (Kerns 2011). Jika sisi dadu tidak 6, maka argument "insides" diganti dengan bilangan yang menyatakan banyaknya sisi dadu yang akan dilantunkan. Untuk menampilkan ruang sampel yang terjadi maka pada argument makespace diisi dengan "F" atau "FALSE". Akan tetapi jika akan dilakukan perhitungan probabilitas maka argument "makespace" harus diisi dengan " $T$ " atau "TRUE".

rolldie (times, nsides $=6$, makespace $=$ FALSE)

Gambar 5. Sintaks percobaan pelantunan dadu

Sebagai contoh penggunaannya perhatikan kasus pelemparan dadu dengan sisi 6 sebanyak 2 kali. Akan ditentukan ruang sampel percobaan tersebut, peluang munculnya jumlah mata dadu 8 , peluang muncul jumlah mata dadu minimal 8 , dan peluang muncul kedua mata dadu sama jika diketahui jumlahnya minimal 8. Untuk menyelesaikan permasalahan pelantunan dadu bersisi 6 ini dibuat program di R dengan nama "PelantunanDadu". Adapun body program yang dikembangkan diberikan pada Gambar 6 dan program tersebut dijalankan dengan sintaks pada Gambar 7. Akan tetapi karena banyaknya anggota ruang sampel 36 maka untuk penulisan hasilnya hanya ditampilkan sebagian saja seperti pada Gambar 8 .

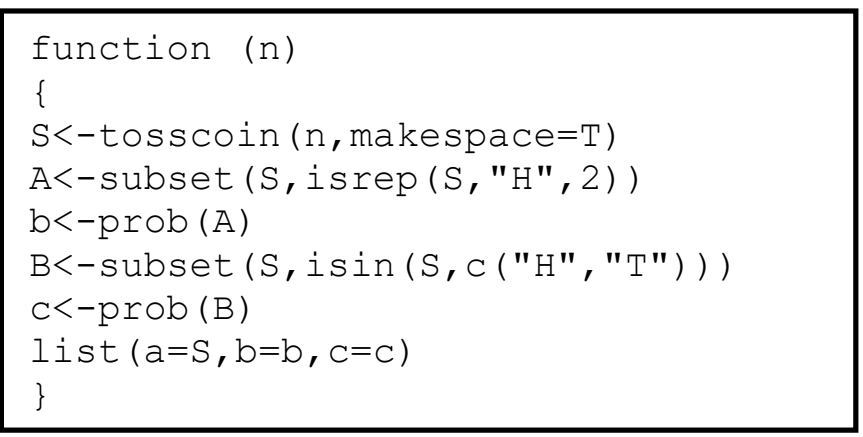

Gambar 6. Body Program "Pelantunan Dadu"

$$
>\text { PelantunanDadu (2) }
$$

Gambar 7. Argumen untuk menjalankan perintah melemparkan dadu 2 kali

Poin (a) menyatakan bagian kemungkinan sampel yang dihasilkan beserta probabilitasnya. Karena sampel yang dihasilkan banyak, pada bab ini hanya ditampilkan sebagian saja, selengkapnya dapat dilihat pada lampiran. Poin (b) menyatakan probabilitas kejadian munculnya jumlah 8 dari kedua lemparan, yaitu 0,1388889 . Poin (c) menyatakan probabilitas munculnya jumlah minimal 8 dari kedua lemparan, yaitu 0,4166667 . Sedangkan poin (d) menyatakan probabilitas munculnya mata 
dadu sama dari kedua lemparan jika diketahui jumlah dari kedua lemparan tersebut minimal 8 , yaitu 0,2 .

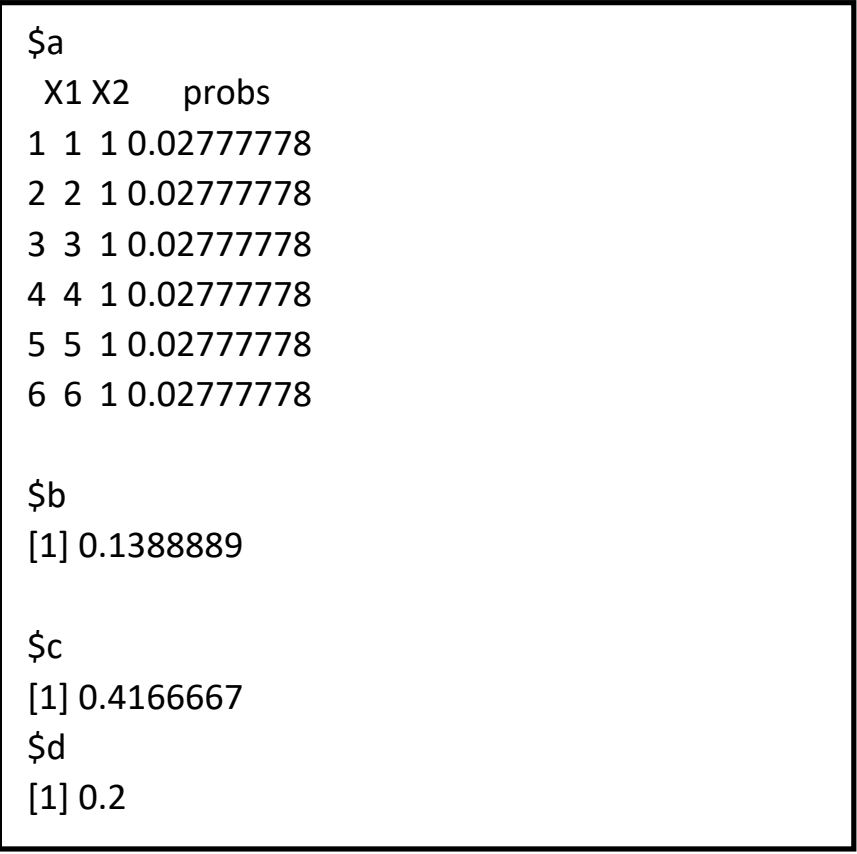

Gambar 8. Hasil output "pelemparan dadu 2 kali"

Jika dikerjakan secara manual, maka pelemparan dadu 2 kali menghasilkan ruang sampel seperti pada Tabel 1 .

Tabel 1. Ruang Sampel Pelemparan dadu 2 kali

\begin{tabular}{cccccccc}
\hline & \multicolumn{6}{c}{ Pelemparan kedua } \\
\cline { 2 - 8 } & & 1 & 2 & 3 & 4 & 5 & 6 \\
Pelemparan & 1 & $(1,1)$ & $(1,2)$ & $(1,3)$ & $(1,4)$ & $(1,5)$ & $(1,6)$ \\
pertama & 2 & $(2,1)$ & $(2,2)$ & $(2,3)$ & $(2,4)$ & $(2,5)$ & $(2,6)$ \\
& 3 & $(3,1)$ & $(3,2)$ & $(3,3)$ & $(3,4)$ & $(3,5)$ & $(3,6)$ \\
& 4 & $(4,1)$ & $(4,2)$ & $(4,3)$ & $(4,4)$ & $(4,5)$ & $(4,6)$ \\
& 5 & $(5,1)$ & $(5,2)$ & $(5,3)$ & $(5,4)$ & $(5,5)$ & $(5,6)$ \\
& 6 & $(6,1)$ & $(6,2)$ & $(6,3)$ & $(6,4)$ & $(6,5)$ & $(6,6)$ \\
\hline
\end{tabular}

Jika kejadian A merupakan kejadian munculnya jumlah 8, maka banyaknya anggota kejadian munculnya jumlah 8 adalah $\mathrm{n}(\mathrm{A})=5$, yaitu $(2,6),(3,5),(4,4),(5,3),(6,2)$. Peluang kejadian munculnya jumlah 8 adalah

$$
P(A)=\frac{n(A)}{n(S)}=\frac{5}{36}=0,13889
$$

Jika B menyatakan kejadian munculnya jumlah minimal 8, maka banyaknya anggota kejadian munculnya jumlah minimal 8 adalah $\mathrm{n}(\mathrm{B})=15$, yaitu $(2,6),(3,5),(4,4),(5,3),(6,2),(3,6),(4,5)$, $(5,4),(6,3),(4,6),(5,5),(6,4),(5,6),(6,5),(6,6)$. Peluang kejadian munculnya jumlah minilah 8 adalah

$$
P(B)=\frac{n(B)}{n(S)}=\frac{15}{36}=0,41667
$$


Jika C menyatakan kejadian munculnya mata dadu sama, maka banyaknya anggota kejadian munculnya mata dadu sama adalah $\mathrm{n}(\mathrm{C})=6$, yaitu $(1,1),(2,2),(3,3),(4,4),(5,5),(6,6)$. Diperoleh $C \cap B=\{(4,4),(5,5),(6,6)\}$ dan $n(C \cap B)=3$. Peluang kejadian munculnya mata dadu sama jika diketahui jumlahnyya minimal 8 adalah

$$
P(C \mid B)=\frac{n(C \cap B)}{n(B)}=\frac{2}{15}=0,2
$$

Hasil ini menunjukkan bahwa dengan menggunakan sintaks software $\mathrm{R}$ dapat dilakukan percobaan pelemparan dadu serta menyelesaikan permasalahan teori probabilitasnya. Perhitungan manual dan pengerjaan menggunakan software $\mathrm{R}$ memberikan hasil yang sama.

Pada percobaan pengambilan item secara acak dari suatu kotak secara umum menurut (Kerns 2011) dilakukan dengan sintaks pada Gambar 9

urnsamples (x, size, replace $=$ FALSE, ordered $=$ FALSE, ...)

Gambar 9. Sintaks percobaan pengambilan item secara acak

Pada sintaks ini, x menyatakan suatu kotak yang berisi sejumlah item dengan beberapa jenis. Kotak ini harus dirancang oleh peneliti sesuai dengan permasalahan yang akan diselesaikan. Argument "size" menyatakan banyaknya item yang akan diambil secara acak. Argumen "replace" menyatakan pengembalian pada pengambilan. Jika pengambilan dilakukan dengan pengembalian, maka argument replace diisi dengan TRUE, tetapi jika pengambilan dilakukan tanpa pengembalian, maka argument replace diisi dengan FALSE. Argumen "ordered" menyatakan urutan sampel yang diperoleh, jika urutan diperhatikan makan argument ordered diisi dengan TRUE, tetapi jika urutan tidak dperhatikan maka Argumen "ordered" diisi dengan FALSE.

Sebagai contoh penggunaannya dapat dilihat pada permasalahan berikut, suatu Kotak berisi 15 bola. Empat bola berwarna merah, 5 hijau dan sisanya biru. Diambil 3 bola tanpa pengembalian. Tentukan Peluang terambil 3 bola biru, peluang muncul bola merah,hijau dan biru, peluang muncul bola secara berurutan merah, hijau dan biru.

Untuk menyelesaikan permasalahan pengambilan item dari kotak ini dibuat program di $\mathrm{R}$ dengan nama "PengambilanItem". Adapun body program yang dikembangkan diberikan pada Gambar 10, program tersebut dijalankan dengan sintaks pada Gambar 11 dan hasilnya ditunjukkan pada Gambar 12.

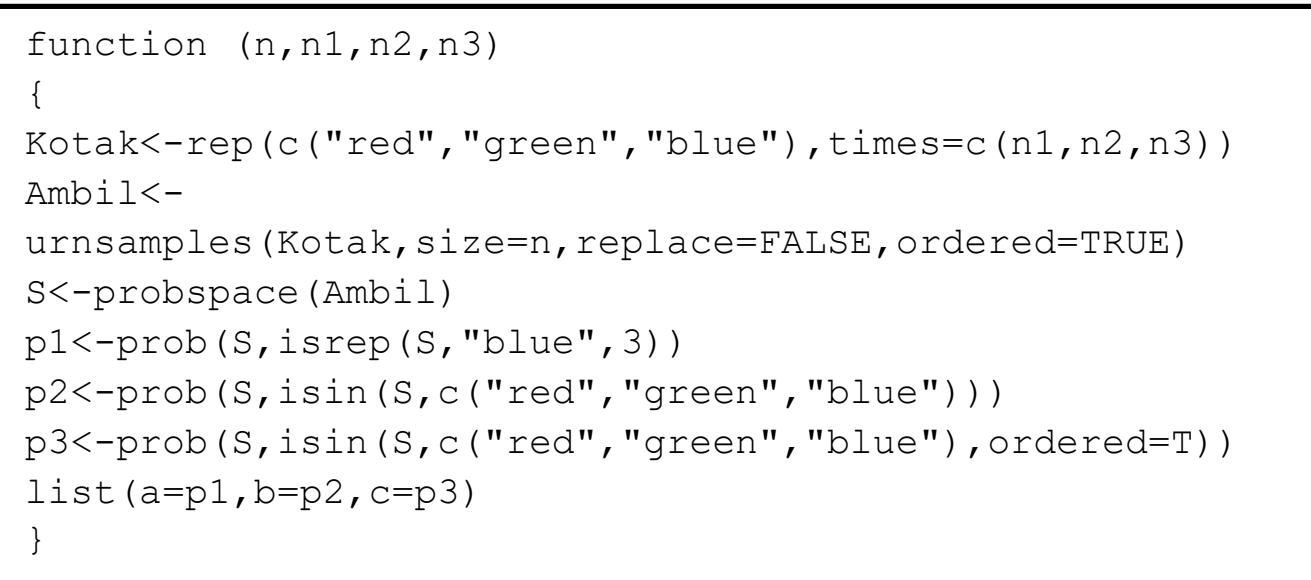

Gambar 10. Body program "pengambilan item"

$>$ PengambilanItem $(3,4,5,6)$

Gambar 11. Argumen untuk menjalankan perintah mengambil item 3 bola biru, hijau, dan biru 
Pada poin (a) menyatakan probabilitas terambil 3 bola biru yaitu 0.04395604 . Point (b) menyatakan probabilitas terambil bola merah, hijau dan biru yaitu 0.2637363 . Sedangkan poin (c) menyatakan probabilitas terambil bola merah, hijau dan biru secara urut yaitu 0.04395604. Output yang dihasilkan terlihat pada Gambar 12.

\begin{tabular}{|l|}
\hline$\$ \mathrm{a}$ \\
{$[1] 0.04395604$} \\
$\$ \mathrm{~b}$ \\
{$[1] 0.2637363$} \\
$\$ \mathrm{c}$ \\
{$[1] 0.04395604$} \\
\hline
\end{tabular}

Gambar 12. Hasil Output "Pelemparan 3 bola"

Pada poin (a) menyatakan probabilitas terambil 3 bola biru yaitu 0.04395604 . Point (b) menyatakan probabilitas terambil bola merah, hijau dan biru yaitu 0.2637363 . Sedangkan poin (c) menyatakan probabilitas terambil bola merah, hijau dan biru secara urut yaitu 0.04395604 .

Jika percobaan tersebut dikerjakan secara manual, maka probabilitas terambil 3 bola biru adalah

$$
P(3 B)=\frac{C_{3}^{6}}{C_{3}^{15}}=0.04395604
$$

Probabilitas terambil bola merah, hijau dan biru adalah

$$
P(M, H, B)=\frac{C_{1}^{4} C_{1}^{5} C_{1}^{6}}{C_{3}^{15}}=0.2637363
$$

Probabilitas terambil bola merah, hijau dan biru secara urut adalah

$$
P(\text { M H B })=\frac{C_{1}^{4}}{C_{1}^{15}} \cdot \frac{C_{1}^{5}}{C_{1}^{14}} \cdot \frac{C_{1}^{6}}{C_{1}^{13}}=0.04395604
$$

Hasil ini menunjukkan bahwa dengan menggunakan sintaks software $\mathrm{R}$ dapat dilakukan percobaan pengambilan item dari kotak serta menyelesaikan permasalahan teori probabilitasnya. Perhitungan manual dan pengerjaan dengan software $\mathrm{R}$ memberikan hasil yang sama.

Percobaan berikutnya adalah pengambilan kartu dari setumpuk kartu bridge. Ruang sampel pengambilan sebuah kartu dari setumpuk kartu bridge dalam $R$ menurut (Kerns 2011) menggunakan sintaks

$$
\text { cards (jokers }=\text { FALSE, makespace }=\text { FALSE) }
$$

Gambar 13. Sintaks percobaan pengambilan kartu secara acak

Jika kartu joker dimasukkan dalam tumpukan kartu, maka argumen " jokers" diisi "T" atau "TRUE", jika kartu joker dikeluarkan dari tumpukan kartu, maka diisi "FALSE". Argumen "makespace" digunakan untuk membuat ruang probabilitasnya, jika akan digunakan untuk menghitung probabilitas kejadian maka argument "makespace" diisi dengan "T" atau "TRUE".

Sebagai contoh penggunaannya dapat dicermati permasalahan pengambilan sebuah kartu dari setumpuk kartu bridge tanpa joker. Tentukan ruang sampelnya, tentukan probabilitas terambilnya kartu "Diamond", tentukan probabilitas terambilnya kartu dengan nomor 3 sampai 6, tentukan 
probabilitas terambilnya kartu "diamond" atau bernomor 3 sampai 6, tentukan probabilitas terambilnya kartu "Diamond" dan bernomor 3 sampai 6.

Untuk menyelesaikan permasalahan pengambilan sebuah kartu dari tumpukan kartu bridge ini dibuat program di R dengan nama "Kartu". Adapun body program yang dikembangkan diberikan sebagai berikut

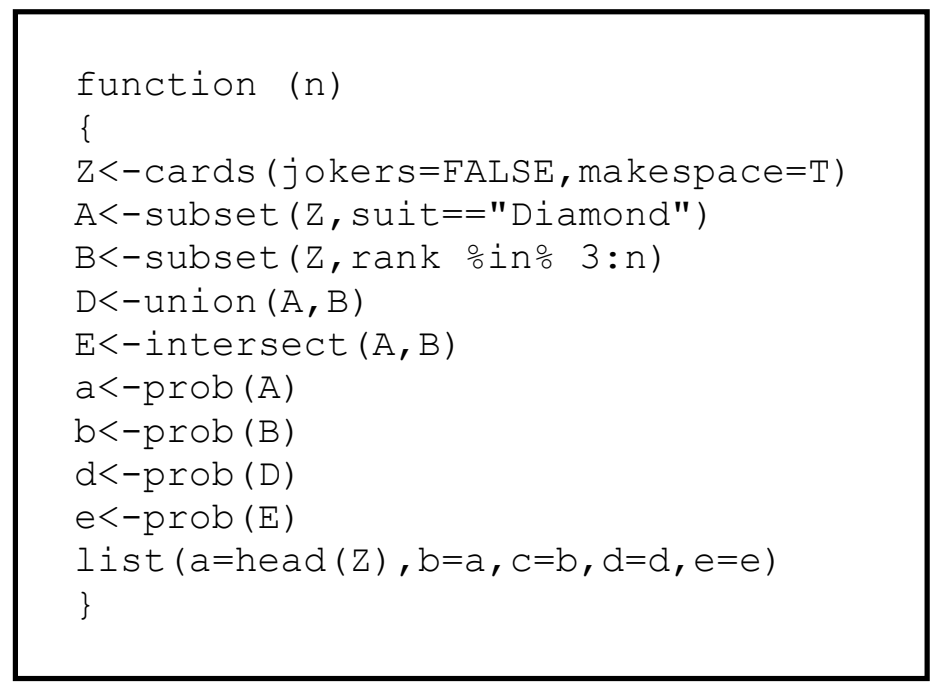

Gambar 13. Body program "pengambilan kartu"

$$
>\operatorname{Kartu}(6)
$$

Gambar 14. Argumen untuk menjalankan perintah "pengambilan kartu"

\begin{tabular}{|l|l|}
\hline \$a & \\
rank suit probs \\
1 & 2 Club 0.01923077 \\
2 & 3 Club 0.01923077 \\
3 & 4 Club 0.01923077 \\
4 & 5 Club 0.01923077 \\
5 & 6 Club 0.01923077 \\
6 & 7 Club 0.01923077 \\
& \\
\$b & \\
{$[1]$} & 0.25 \\
\$c & \\
{$[1]$} & 0.3076923 \\
\$d & \\
{$[1]$} & 0.4807692 \\
\$e & \\
{$[1]$} & 0.07692308 \\
\hline
\end{tabular}

Gambar 15. Hasil output "pengambilan kartu"

Pada poin (a) menyatakan bagian ruang sampel yang terbentuk. Poin (b) menyatakan probabilitas munculnya kartu "Diamond" yaitu 0,25. Poin (c) menyatakan probabilitas terambilnya kartu 
bernomor 3 sampai 6 yaitu 0,307923. Poin (d) menyatakan probabilitas terambilnya kartu "Diamond" atau bernomor 3 ampai 6, yaitu 0,4807692. Sedangkan poin $€$ menyatakan probabilitas terambilnya kartu "Diamond" dan bernomor 3 sampai 6, yaitu 0,07692308.

Jika permasalahan tersebut dikerjakan secara manual maka ruang sampel yang terbentuk berisi semua kartu bridge tanpa kartu joker, yaitu sejumlah $n(S)=52$ kartu. Jika A menyatakan kejadian munculnya kartu "Diamond" maka $(A)=13$. Probabilitas munculnya kartu "Diamond" adalah

$$
P(A)=\frac{n(A)}{n(S)}=\frac{13}{52}=0,25
$$

Jika B menyatakan kejadian munculnya kartu bernomor 3 sampai 6 maka $n(B)=16$. Probabilitas munculnya kartu bernomor 3 sampai 6 adalah

$$
P(A)=\frac{n(A)}{n(S)}=\frac{16}{52}=0,3076923
$$

Banyaknya anggota kejadian $A \cup B$ adalah $n(A \cup B)=25$. Probabilitas $A \cup B$ adalah

$$
P(A \cup B)=\frac{n(A \cup B)}{n(S)}=\frac{25}{52}=0,4807692
$$

Banyaknya anggota kejadian $A \cap B$ adalah $n(A \cap B)=4$. Probabilitas $A \cap B$ adalah

$$
P(A \cap B)=\frac{n(A \cap B)}{n(S)}=\frac{4}{52}=0,07692308
$$

Hasil ini menunjukkan bahwa dengan menggunakan sintaks software $\mathrm{R}$ dapat dilakukan percobaan pengambilan kartu dari setumpuk kartu bridge serta menyelesaikan permasalahan teori probabilitasnya. Perhitungan manual dan pengerjaan dengan software $\mathrm{R}$ memberikan hasil yang sama. Penggunaan software $\mathrm{R}$ dalam pembelajaran teori probabilitas ini dapat dijadikan sebuah inovasi atau terobosan dalam pembelajaran. Hal ini sejalan dengan penelitian yang dilakukan (Rahayu and Rohimah 2015), yang menyatakan bahwa inovasi pembelajaran bagi guru matematika SMA dan SMK dapat dilakukan melalui penggunaan software R.

\section{Simpulan}

Pembelajaran teori probabilitas tidak selamanya harus dilakukan secara manual. Software $\mathrm{R}$ dapat digunakan untuk pembelajaran teori probabilitas melalui simulasi percobaan serta melakukan perhitungan terkait permasalahan probabilitas. Sintaks dasar yang sudah ada pada $\mathrm{R}$ dapat dikembangkan untuk mempelajari materi probabilitas yang lebih komplek. Percobaan yang digunakan dalam teori probabilitas seperti pelemparan mata uang logam, pelantunan dadu, pengambilan item dari kotak dan pengambilan kartu dari setumpuk kartu bridge dapat dilakukan dengan Software R. Penyelesaian permasalahan probabilitas terkait identifikasi ruang sampel, operasi kejadian, probabilitas kejadian, probabilitas bersyarat dapat diselesaikan menggunakan R. Hal ini membantu peserta didik khususnya mahasiswa dalam mempelajari teori probabilitas.

\section{Referensi}

Aisyah, Maizatul Nur, Bambang Sumintono, and Zaleha Ismail. 2014. "PEMAHAMAN SISWA PADA POKOK BAHASAN PELUANG: STUDI KASUS DI SATU SEKOLAH MENENGAH DI JOHOR BAHRU, MALAYSIA.” JJurnal Pengajaran MIPA 19 (1): 19-28. https://doi.org/10.1101/2020.11.10.376129.

Bain, L.J., and Engelhardt, M. 1992. Introduction to Probability and Mathematical Statistics. 2nd ed. California: Duxbury Press.

Budiyono. 2009. Statistika Untuk Penelitian. Surakarta: UNS Press.

Dalgaard, P. 2008. Introductory Statistics with R. 2nd ed. Springer.

Hartanto. 2016. Pengenalan Analisis Statistik Dengan Software R. Yogyakarta: Magnum Pustaka Jaya. 
Kerns, G J. 2011. Introduction to Probability and Statistics Using R. 1st ed.

Parsa, I Made. 2013. "Kajian Pendekatan Teori Probabilitas Untuk Pemetaan Lahan Sawah Berbasis Perubahan Penutup Lahan Citra Landsat Multiwaktu ( Studi Kasus Daerah Tanggamus , Lampung ).” Jurnal Penginderaan Jauh Dan Pengolahan Citra Digital 10 (2): $113-21$.

Rahayu, Widyanti, and Siti Rohmah Rohimah. 2015. "Meningkatkan Keterampilan Menggunakan Software R Sebagai Solusi Untuk Meningkatkan Inovasi Pembelajaran Bagi Guru-Guru Matematika Sma Dan Smk Di Jakarta Timur." Sarwahita 12 (2): 134-40. https://doi.org/10.21009/sarwahita.122.10.

Relawati, Relawati, and Eni Defitriani. 2018. "Meningkatkan Aktivitas Dan Hasil Belajar Mata Kuliah Teori Probabilitas Semester 2 Prodi Pendidikan Matematika FKIP UNBARI Jambi Melalui Metode Permainan Kartu.” Jurnal Ilmiah Universitas Batanghari Jambi 18 (3): 552. https://doi.org/10.33087/jiubj.v18i3.522.

Rohatgi, V K, and A K M E Saleh. 2015. An Introduction to Probability and Statistics. 3rd ed. Wiley Series in Probability and Statistics.

Sari, Dwi Ivayana. 2015. "Profil Berpikir Probabilistik Siswa Sekolah Dasar (SD) Berkemampuan Matematika Tinggi Dalam Menyelesaikan Tugas Probabilitas." Seminar Nasional Matematika Dan Pendidikan Matematika UNY, no. 2: 1123-30.

Sari, Dwi Ivayana, I Ketut Budayasa, and Dwi Juniati. 2018. "Perkembangan Berpikir Probabilistik Siswa Sekolah Dasar." Jurnal Riset Pendidikan Dan Inovasi Pembelajaran Matematika (JRPIPM) 1 (1): 30. https://doi.org/10.26740/jrpipm.v1n1.p30-39.

Sharma, Sashi. 2012. "Sashi Sharma U Canada" 4 (5): 63-77.

Sirait, S, and O.N Purba. 2018. "Peningkatan Penguasaan Kombinatorik Pada Mata Kuliah Probabilitas Dengan Menggunakan Combination Box" III (1): 89-96.

William N Venables, David M Smith. 2009. An Introduction to R: A Programming Environment for Data Analysis Ang Graphics. 2nd ed. Network Theory Ltd. 